\title{
Performance of a whole tree mechanised timber harvesting system when clear-felling a 32-year-old Pinus taeda L. stand
}

\author{
Natali de Oliveira Pitz ${ }^{1}$; Jean Alberto Sampietro ${ }^{1 *}$; Erasmo Luis Tonett ${ }^{1}$; Luis Henrique Ferrari ${ }^{1}$; \\ Philipe Ricardo Casemiro Soares ${ }^{1}$; Marcelo Bonazza ${ }^{2}$; Daiane Alves de Vargas ${ }^{1}$; Marcos Felipe Nicolleti ${ }^{1}$; \\ Renato Cesar Gonçalves Robert ${ }^{3}$ \\ ${ }^{1}$ Department of Forest Engineering, Santa Catarina State University (UDESC), Lages, Santa Catarina, Brazil. \\ ${ }^{2}$ Department of Agriculture, Biodiversity and Forests, Federal University of Santa Catarina, Curitibanos, Santa Catarina, Brazil. \\ ${ }^{3}$ Department of Forest Engineering and Technology, Federal University of Paraná (UFPR), Curitiba, Paraná, Brazil. \\ *Corresponding author: jean.sampietro@udesc.br
}

(Received for publication 27 January 2020; accepted in revised form 29 September 2021)

\begin{abstract}
Background: Work studies are fundamental for the development and assessment of timber harvesting systems aimed at rationalising and improving forest management activities.

Methods: This study evaluated the operational performance of a mechanised whole-tree harvesting system in 32-yearold Pinus taeda L. stands producing multiple timber products. A time and motion study at the cycle element level was conducted to evaluate the operational performance of each component of the harvesting system. Equations were developed to estimate the productivity of tree extraction activity with a wheeled skidder and log loading with a mechanical loader.

Results: Tree felling with an excavator-based harvester had the highest mean productivity (135 $\mathrm{m}^{3}$ per productive machine hour), followed by tree extraction with a wheeled skidder $\left(117 \mathrm{~m}^{3}\right.$ per productive machine hour), while manually processing larger logs with a chainsaw had the lowest productivity $\left(25.7 \mathrm{~m}^{3}\right.$ per productive machine hour). Operator, extraction distance and mean log volume had a significant effect on the performance of different activities and were included in productivity models.

Conclusions: Operational performance of equipment was variable and dependent on the effect of the operator, extraction distance and log volume. Thus, the use of models to estimate productivity considering such factors, coupled with reduced delays to increase utilisation of equipment, will contribute to the better management and planning of forest harvesting operations under the evaluated conditions.
\end{abstract}

Keywords: forest operations and techniques; work study; forest mechanisation.

\section{Introduction}

The management of planted pine forests is a consolidated activity in Brazil, both by vertically integrated companies and independent producers. However, the forest management strategies adopted by vertically integrated companies differ from those adopted by independent producers, who typically aim to diversify forest production to market logs for different industrial segments. When the objective of forest production is diversification of timber products, the planted forests in Brazil are usually managed on longer rotations (i.e. around 30 years), which requires the need for thinning, before the final cutting of the stand occurs. Such a prescription affects the performance dynamics of forest operations, with several differences compared to those observed in short rotation planted forests. Working conditions in final cutting operations tend to allow higher operational performance and lower unit costs 
compared to thinning operations. One of the key factors driving this is better access and mobility for machinery traffic due to the relatively small number of trees per unit area remaining at the final cutting. Because these trees have larger dimensions and volumes, this results in lower specific time consumption and higher productivity of harvesting equipment (Ghaffariyan et al. 2012; Strandgard et al. 2013; Walsh \& Strandgard 2014).

However, the large size of the trees can lead to increased safety risks, which implies the use of specific techniques when performing cutting and extraction activities. In addition, a wide variety of log assortments are produced, which increases the complexity of operational aspects of pre-extraction, stacking and organisation of timber.

In Brazil, these forest operations are carried out predominantly using cut-to-length (CTL) or whole-tree (WT) harvesting systems (Seixas \& Oliveira Júnior 2001). In most cases the typical WT harvesting systems consist of a feller-buncher, skidders and processors, where only one machine perform all the tree bucking and processing (Rocha et al. 2009; Lopes et al. 2017; Diniz et al. 2018a; Rodrigues et al. 2019). However, there a very few studies analysing this system in Brazilian pine plantations managed on longer rotations, (Pereira et al. 2015; Souza et al. 2018), especially when machinery configurations differ from the typical WT system.

The evaluation of timber harvesting systems is essential for correcting and changing the production process to rationalise and optimiseresources (Magagnotti \& Spinelli 2012; Ackerman et al. 2014; Szewczyk et al. 2017). It is also an indispensable instrument for comparing different methods or equipment (Spinelli et al. 2014; Marčeta \& Košir 2016; Pajkoš et al. 2018).

Our study aimed to: (i) evaluate the operational performance of a mechanised whole tree harvesting system in the final cutting of Pinus taeda stands; (ii) verify the effect of operational factors on specific time consumption and productivity; and (iii) model the relationship between productivity and operational factors to provide information to improve management of these activities.

\section{Methods}

\section{Study site and stand characteristics}

The study was conducted in a commercial forest stand in Capão Alto, Santa Catarina State, Brazil. The terrain slope was level to gentle according to Forestry Commission UK (1996) $\left(\right.$ Level $=0^{\circ}-6^{\circ}$, Gentle $=6^{\circ}-11^{\circ}$, Moderate $=11^{\circ}-18^{\circ}$, Steep $=18^{\circ}-27^{\circ}$, Very Steep $=>27^{\circ}$ ) and the climate is classified as $\mathrm{Cfb}$ according to Köppen-Geiger with no defined dry season, and mild summers (Peel et al. 2007). The annual mean temperature ranges from 14 to $16^{\circ} \mathrm{C}$ and the annual precipitation is between 1600 to 1900 mm (Alvares et al. 2013). The forest stand consisted of Pinus taeda and its purpose was to produce wood for multiple uses, so it was subjected to four thinning interventions. Our study was performed when the stand was undergoing the final felling, at the age of 32 years, with a stand density of 357 trees/ha, mean diameter at breast height of $45 \mathrm{~cm}$, mean total height of $31 \mathrm{~m}$ and a mean individual tree volume of $2.46 \mathrm{~m}^{3}$.

\section{Harvesting operations}

We evaluated a mechanised "whole tree" harvesting system configured to produce different demands of log assortments for different destinations. The system consisted of an excavator-based harvester (CAT FM 320D) coupled to a 7000XT Logmax head which felled the trees and a wheeled grapple skidder (John Deere $748 \mathrm{H}$ ), which extracted the trees from the cutting area to the roadside landing, with an extraction distance ranging from 30 to $310 \mathrm{~m}$.

At the roadside landing area, the trees were bucked and processed in three stages by different equipment. The first logs cut from the trees (large logs) were destined for sawmills and lamination plants, and had volumes ranging from 0.232 to $0.870 \mathrm{~m}^{3} \log ^{-1}$, smallend diameters ranging from 35 to $70 \mathrm{~cm}$ and, often had an irregular shape at the base. These were manually processed using a chainsaw (Stihl MS 361) due to the limitations of other cutting equipment.

The intermediate volume logs (medium logs), destined for sawmills with volumes between 0.157 to $0.227 \mathrm{~m}^{3} \log ^{-1}$ and diameter at the smaller end ranging from 25 to $35 \mathrm{~cm}$, were processed using a mechanical slasher coupled to a Caterpillar 320B. The lower volume logs (small logs), destined for pulp and mechanical processing with volumes between 0.087 to $0.132 \mathrm{~m}^{3} \mathrm{log}$ ${ }^{1}$ and small-end diameters ranging from 8 to $25 \mathrm{~cm}$, were processed by the same excavator-based harvester that was used for tree felling, but at a later point in time.

The logs were stacked into product piles and organised in seven different log assortments according to small-end diameter and presence/absence of knots with lengths ranging from 1.90 to $3.10 \mathrm{~m}$. After a period of between two to five days, the logs were loaded onto transport vehicles with a mechanical crawler loader (Caterpillar 320B). The work schedule and utilisation of each piece of equipment within the harvesting system depended on commercial production needs and operational work restrictions. Wood residues were not taken back into the stand.

\section{Performance evaluation}

The operational performance of the activities was assessed by time and motion study at the cycle element level following the modelling approach (Magagnotti \& Spinelli 2012). The work cycle of each piece of equipment was divided into elements (Table 1) and then the time consumption was measured by the individual time clocking technique using a centesimal chronometer and specific forms. The number of trees felled, extracted or bucked at each working cycle was recorded. The volume produced at each working cycle (in cubic meters of solid wood over bark) was determined by multiplying the number of trees (or logs) by the mean individual tree (or log) volume for the stand. Data on the volumes of individual trees and logs for the stand were obtained from the forestry company's inventory records. 
TABLE 1: Elements of the work cycle of each equipment and function/activity of harvesting system.

\begin{tabular}{|c|c|c|c|}
\hline Equipment & Function/activity & Work cycle element & Description \\
\hline \multirow{3}{*}{$\begin{array}{l}\text { Excavator- } \\
\text { based } \\
\text { harvester }\end{array}$} & \multirow{3}{*}{ Tree felling } & Movement (MV) & Equipment moving to the target tree \\
\hline & & $\begin{array}{l}\text { Boom movement and } \\
\text { tree felling }(\mathrm{BF})\end{array}$ & Boom swings towards tree and executes felling \\
\hline & & $\begin{array}{l}\text { Drop and bunch } \\
\text { organisation (DB) }\end{array}$ & Felled trees dropped and organised into bunches \\
\hline \multirow{4}{*}{$\begin{array}{l}\text { Wheeled } \\
\text { skidder }\end{array}$} & \multirow{4}{*}{ Tree extraction } & Travelling empty (TE) & $\begin{array}{l}\text { Movement of equipment from roadside landing to } \\
\text { cutting area, close to the felled tree bunch }\end{array}$ \\
\hline & & $\begin{array}{l}\text { Manoeuvring and } \\
\text { loading (ML) }\end{array}$ & $\begin{array}{l}\text { Manoeuvring and loading of the tree bunch in the } \\
\text { equipment's grapple }\end{array}$ \\
\hline & & Travelling loaded (TL) & $\begin{array}{l}\text { Movement of equipment with tree bunch from } \\
\text { cutting area to roadside landing area }\end{array}$ \\
\hline & & $\begin{array}{l}\text { Unloading and } \\
\text { manoeuvring (UM) }\end{array}$ & $\begin{array}{l}\text { Manoeuvring and unloading the of tree bunch at the } \\
\text { roadside }\end{array}$ \\
\hline \multirow{3}{*}{$\begin{array}{l}\text { Manual } \\
\text { chainsaw }\end{array}$} & \multirow{3}{*}{$\begin{array}{l}\text { Processing larger } \\
\log s^{1}\end{array}$} & Movement (MV) & $\begin{array}{l}\text { Worker moves towards bunch of trees to execute log } \\
\text { bucking }\end{array}$ \\
\hline & & $\begin{array}{l}\text { Log measurement } \\
(\mathrm{LM})\end{array}$ & $\begin{array}{l}\text { Worker measures the logs length with a stick and } \\
\text { marks the location for cross-cutting }\end{array}$ \\
\hline & & Tree bucking (TB) & $\begin{array}{l}\text { Worker executes the crosscut and, if necessary, } \\
\text { delimbs some branches }\end{array}$ \\
\hline \multirow{4}{*}{$\begin{array}{l}\text { Mechanical } \\
\text { slasher }\end{array}$} & \multirow{4}{*}{$\begin{array}{l}\text { Processing medium } \\
\log s^{2}\end{array}$} & Boom movement (BM) & Boom swings towards to the stem bunch \\
\hline & & $\begin{array}{l}\text { Accumulation and } \\
\text { organisation }(\mathrm{AO})\end{array}$ & $\begin{array}{l}\text { Stem accumulation and organisation in mechanical } \\
\text { slasher }\end{array}$ \\
\hline & & Stem bucking (SB) & $\begin{array}{l}\text { The mechanical slasher's saw is activated and cuts } \\
\text { the bunched stems }\end{array}$ \\
\hline & & $\begin{array}{l}\text { Swinging loaded } \\
\text { grapple (SG) }\end{array}$ & Swinging loaded grapple with logs \\
\hline \multirow{3}{*}{$\begin{array}{l}\text { Excavator- } \\
\text { based } \\
\text { harvester }\end{array}$} & \multirow{3}{*}{$\begin{array}{l}\text { Processing small } \\
\log s^{3}\end{array}$} & Movement (MV) & Equipment moves to the stem bunch \\
\hline & & Boom movement (BM) & Boom swings towards the bunched stems \\
\hline & & Processing logs (PR) & $\begin{array}{l}\text { The processor head's saw is activated and cuts the } \\
\text { bunched stems }\end{array}$ \\
\hline \multirow{4}{*}{$\begin{array}{l}\text { Mechanical } \\
\text { loader }\end{array}$} & \multirow{4}{*}{$\begin{array}{l}\text { Loading logs onto } \\
\text { the trucks }\end{array}$} & $\begin{array}{l}\text { Swinging empty } \\
\text { grapple (SEG) }\end{array}$ & $\begin{array}{l}\text { Empty grapple (unloaded) swings towards to the log } \\
\text { pile }\end{array}$ \\
\hline & & Grappling logs (GAL) & $\begin{array}{l}\text { Log bunch accumulation and organisation in } \\
\text { equipment grapple }\end{array}$ \\
\hline & & Swinging logs (SLG) & $\begin{array}{l}\text { Grapple loaded with logs swings towards to the } \\
\text { trailer or semi-trailer of secondary transport vehicle }\end{array}$ \\
\hline & & $\begin{array}{l}\text { Bunking the logs in } \\
\text { the truck (BAT) }\end{array}$ & $\begin{array}{l}\text { Bunking the logs in the trailer or semi-trailer of } \\
\text { secondary transport vehicle }\end{array}$ \\
\hline
\end{tabular}

\footnotetext{
${ }^{1}$ Logs destined for sawmills and lamination with volume ranging from 0.232 to $0.870 \mathrm{~m}^{3} \log ^{-1}$.

${ }^{2}$ Logs destined for sawmills with volume ranging from 0.157 to $0.227 \mathrm{~m}^{3} \log ^{-1}$.

${ }^{3}$ Logs destined for pulp and mechanical processing with volumes ranging from 0.087 to $0.132 \mathrm{~m}^{3} \log ^{-1}$.
} 
Data referring to the operational performance factors were also measured for each working cycle. The operator $(\mathrm{Op})$ was considered a fixed-effect factor and different operators were only evaluated for the wheeled skidder and the mechanical loader. The slope (in degrees) was assessed with a TruPulse 360 Laser Rangefinder. The extraction distance (ED, in meters) for a wheeled skidder, which corresponded to the distance between where the skidder stopped to load trees and then stopped to unload trees, was measured with the same device also used to assess the slope. The mean log volume ( $\mathrm{LV}$, in $\left.\mathrm{m}^{3} \log ^{-1}\right)$ for the mechanical loader was calculated by dividing the total loaded volume in a cycle by the number of logs loaded in the same cycle.

The specific time consumption $\left(\mathrm{s} \mathrm{m}^{-3}\right)$ was calculated as the ratio between the time consumed for each element and the production in the respective work cycle. The productivity per productive machine hour without any delays $\left(P_{\mathrm{PMH}}, \mathrm{m}^{3} \mathrm{PMH}_{0}^{-1}\right)$ was calculated as the ratio between the production in the work cycle and the total time consumed in the respective cycle (excluding delays). Delay times were recorded and classified according to the IUFRO time model (Björheden et al. 1995) so that the availability $(A R)$ and utilisation rate $(U R)$ could be calculated according to Ackerman et al. (2014).

\section{Data analysis}

Specific time consumption and $P_{\mathrm{PMH}}$ data were analysed by descriptive statistics and expressed as box and whisker plots. The estimation error for the $P_{\mathrm{PMH}}$ variable was determined at the $95 \%$ level of probability significance, according to Szewczyk et al. (2017). The effect of influential factors for some activities was analysed using ANOVA. Prior to analysis, the data were subjected to a Kolmogorov-Smirnov normality test at $5 \%$ significance level and, in the case of non-normality, were mathematically transformed to achieve normality.

For tree extraction activity with the wheeled skidder and log loading with the mechanical loader, multiple linear regression equations were fitted using a stepwise approach to test the effect of different independent variables on $P_{\mathrm{PMH}}$. Goodness of fit for the models was evaluated by the adjusted coefficient of determination and absolute and relative standard errors of estimates.

\section{Results}

\section{Mean values, estimation errors, and ratios of performance measures}

Among the activities and equipment evaluated, the highest estimation error $(\varepsilon)$ was found for processing medium logs with the mechanical slasher ( $\varepsilon=9.80 \%)$, followed by tree extraction with a wheeled skidder ( $\mathcal{E}=8.88 \%$ ) (Table 2 ). The activity of processing large logs with the manual chainsaw had the highest $A R$ but the highest mean $T_{\text {cycle }}$, lowest mean $P_{\mathrm{PMH}}$ and $U R$ (Table 2 ). The highest operational performance was observed in the activity of tree felling with the excavator-based harvester $\left(T_{\text {cycle }}=32.4 \mathrm{~s} \mathrm{~m}^{-3}\right.$ and $\left.P_{\mathrm{PMH}}=135 \mathrm{~m}^{3} \mathrm{PMH}_{0}^{-1}\right)$, although this had the lowest $A R(66.2 \%)$, and for the tree extraction with the wheeled skidder $\left(T_{\text {cycle }}=45.8 \mathrm{~s} \mathrm{~m}^{-3}\right.$ and $P_{\mathrm{PMH}}=117 \mathrm{~m}^{3} \mathrm{PMH}_{0}^{-1}$ ), which had the highest UR $(61.0 \%)$.

TABLE 2: Mean values ( \pm standard deviation) for total time taken per work cycle, volume per cycle, productivity per productive machine hour, estimation error, availability and utilisation rate for each piece of equipment and function/activity of the harvesting system.

\begin{tabular}{|c|c|c|c|c|c|c|c|c|}
\hline Equipment & $\begin{array}{l}\text { Function/ } \\
\text { activity }\end{array}$ & $\begin{array}{l}T_{\text {cycle }} \\
\left(\mathrm{S} \mathrm{m}^{-3}\right)\end{array}$ & $\begin{array}{l}V_{\text {cycle }} \\
\left(\mathrm{m}^{3} \text { cycle }^{-1}\right)\end{array}$ & $\begin{array}{l}P_{\mathrm{PMH}} \\
\left(\mathrm{m}^{3} \mathrm{PMH}_{0}^{-1}\right)\end{array}$ & $\begin{array}{l}\text { n } \\
\text { (cycles) }\end{array}$ & $\begin{array}{l}\varepsilon \\
(\%)\end{array}$ & $\begin{array}{l}A R \\
(\%)\end{array}$ & $\begin{array}{l}U R \\
(\%)\end{array}$ \\
\hline $\begin{array}{l}\text { Excavator-based } \\
\text { harvester }\end{array}$ & Tree felling & $\begin{array}{l}32.39 \\
( \pm 14.33)\end{array}$ & $\begin{array}{l}2.46 \\
( \pm 1.28)\end{array}$ & $\begin{array}{l}135.05 \\
( \pm 61.86)\end{array}$ & 223 & 5.95 & 66.2 & 44.5 \\
\hline Wheeled skidder & Tree extraction & $\begin{array}{l}45.80 \\
( \pm 33.94)\end{array}$ & $\begin{array}{l}6.60 \\
( \pm 2.47)\end{array}$ & $\begin{array}{l}117.19 \\
( \pm 71.60)\end{array}$ & 276 & 8.88 & 93.2 & 61.0 \\
\hline Manual chainsaw & $\begin{array}{l}\text { Processing larger } \\
\operatorname{logs}^{1}\end{array}$ & $\begin{array}{l}167.59 \\
( \pm 118.18)\end{array}$ & $\begin{array}{l}0.498 \\
( \pm 0.158)\end{array}$ & $\begin{array}{l}25.69 \\
( \pm 10.99)\end{array}$ & 416 & 4.35 & 94.7 & 49.3 \\
\hline $\begin{array}{l}\text { Mechanical } \\
\text { slasher }\end{array}$ & $\begin{array}{l}\text { Processing } \\
\text { medium logs }\end{array}$ & $\begin{array}{l}79.18 \\
( \pm 42.39)\end{array}$ & $\begin{array}{l}0.937 \\
( \pm 0.301)\end{array}$ & $\begin{array}{l}61.69 \\
( \pm 36.70)\end{array}$ & 246 & 9.80 & 90.1 & 50.0 \\
\hline $\begin{array}{l}\text { Excavator-based } \\
\text { harvester }\end{array}$ & $\begin{array}{l}\text { Processing small } \\
\log s^{3}\end{array}$ & $\begin{array}{l}46.67 \\
( \pm 20.18)\end{array}$ & $\begin{array}{l}1.743 \\
( \pm 0.932)\end{array}$ & $\begin{array}{l}98.87 \\
( \pm 64.54)\end{array}$ & 513 & 3.58 & 89.7 & 34.5 \\
\hline $\begin{array}{l}\text { Mechanical } \\
\text { loader }\end{array}$ & $\begin{array}{l}\text { Loading logs onto } \\
\text { the trucks }\end{array}$ & $\begin{array}{l}68.88 \\
( \pm 55.44)\end{array}$ & $\begin{array}{l}0.960 \\
( \pm 0.421)\end{array}$ & $\begin{array}{l}76.64 \\
( \pm 43.56)\end{array}$ & 502 & 6.32 & 86.7 & 29.9 \\
\hline
\end{tabular}

\footnotetext{
${ }^{1}$ Logs destined for sawmills and lamination with volume ranging from 0.870 to $0.232 \mathrm{~m}^{3} \log ^{-1}$.

${ }^{2}$ Logs destined for sawmills with volume ranging from 0.227 to $0.157 \mathrm{~m}^{3} \log ^{-1}$.

${ }^{3}$ Logs destined for pulp and mechanical processing with volume ranging from 0.132 to $0.087 \mathrm{~m}^{3} \log ^{-1}$.
} 


\section{Time consumption and effect of factors on performance}

For tree felling with an excavator-based harvester, BF was the element that consumed most time within the work cycle (Figure 1a). There was also a significant effect of ground slope on the time consumed in this element (Table 3). For tree extraction with a wheeled skidder (Figure 1b), TL and TE were the elements that consumed most time in the work cycle; they varied significantly between machine operators as indicated by ANOVA (Table 3). Significant differences between machine operators were also observed on all other variables related to operational performance, except UM (Table 4). On average, Operator 2 took more time and extracted $10.2 \%$ less volume per work cycle than Operator 1, resulting in a $27.6 \%$ mean productivity difference (mean $P_{\mathrm{PMH}}$ of $146 \mathrm{~m}^{3} \mathrm{PMH}_{0}^{-1}$ for Operator 1 compared with 82.8 $\mathrm{m}^{3} \mathrm{PMH}_{0}^{-1}$ for Operator 2).

Ground slope had a significant effect on the TL, UM and $\mathrm{V}_{\text {cycle }}$ elements, which was due to the increased difficulty of working on steeper slopes. However, there was no significant effect of slope on $T_{\text {cycle }}$ and $P_{\text {РMH. }}$ Extraction distance had a significant effect on all variables assessed for the skidder operation, except $\mathrm{V}_{\text {cycle }}$. It was also the single explanatory variable in the models for wheeled loader productivity (Table 4). Even though there was a significant difference in performance between the two operators, longer extraction distances resulted in more time being consumed which consequently reduced productivity (Figure 2a).

Among the tree processing activities, more time per work cycle was consumed using a manual chainsaw (Figure 1c) compared with a mechanical slasher and excavator-based harvester (Figure $1 \mathrm{~d}$ and $1 \mathrm{e}$, respectively). Most of the time consumed in the manual chainsaw work cycle occurred at the TB element due to the large size of the logs and, as already mentioned, because the activity was performed with manual equipment. AO was the element that consumed most of the work cycle time for processing medium logs with the mechanical slasher (Figure 1d). In the case of processing small logs with the excavator-based harvester, most of the time consumed in the work cycle was with the PR element.

There was a significant difference in the work cycle times between the two operators (Figure 1f, Table 3), but there was also a significant effect of mean log volume. In general, the BAT element was responsible for most of the time taken during the work cycle (Figure 1f), which was due to the need to optimise the space occupied by the load on trucks.

FIGURE 1: Boxplot (showing quartiles, minimum, maximum and mean values) of specific time consumed for each work cycle element for each evaluated activity, equipment and operator (if applicable), where: (a) tree felling with the excavator-based harvester, (b) tree extraction with the wheeled skidder, (c) processing larger logs with the manual chainsaw, (d) processing medium logs with the mechanical slasher, (e) processing small logs with the excavator-based harvester and (f) loading log with mechanical loader.
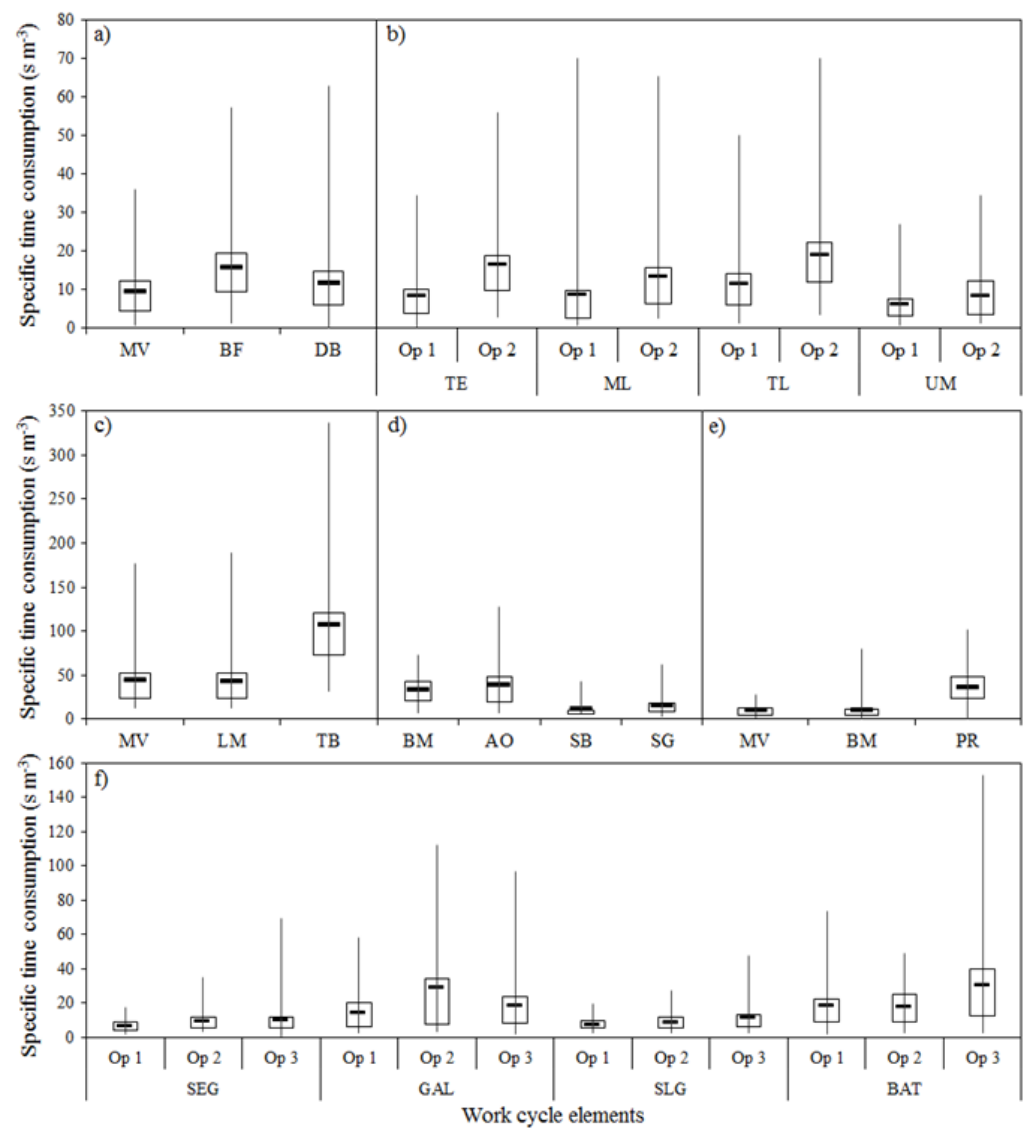
TABLE 3: ANOVA results showing the significance of different factors on aspects of operational performance.

\begin{tabular}{|c|c|c|c|c|c|c|}
\hline \multirow[t]{2}{*}{ Equipment } & \multirow[t]{2}{*}{ Function } & \multirow[t]{2}{*}{ Performance metric } & \multicolumn{4}{|c|}{ Factors affecting performance } \\
\hline & & & Slope & Operator & Extraction distance & Log volume \\
\hline \multirow{5}{*}{$\begin{array}{l}\text { Excavator-based } \\
\text { harvester }\end{array}$} & \multirow[t]{5}{*}{ Tree felling } & MV & 0.494 & - & - & - \\
\hline & & $\mathrm{BF}$ & 0.030 & - & - & - \\
\hline & & $\mathrm{DB}$ & 0.978 & - & - & - \\
\hline & & $\mathrm{T}_{\text {cycle }}$ & 0.779 & - & - & - \\
\hline & & $\mathrm{P}_{\mathrm{PMH}}$ & 0.648 & - & - & - \\
\hline \multirow[t]{7}{*}{ Wheeled skidder } & \multirow{7}{*}{$\begin{array}{l}\text { Tree } \\
\text { extraction }\end{array}$} & $\mathrm{TE}$ & 0.181 & $<0.001$ & $<0.001$ & - \\
\hline & & ML & 0.262 & 0.002 & $<0.001$ & - \\
\hline & & $\mathrm{TL}$ & 0.002 & 0.002 & $<0.001$ & - \\
\hline & & UM & $<0.001$ & 0.277 & 0.018 & - \\
\hline & & $\mathrm{T}_{\text {cycle }}$ & 0.267 & $<0.001$ & $<0.001$ & - \\
\hline & & $\mathrm{V}_{\text {cycle }}$ & 0.035 & $<0.001$ & 0.942 & - \\
\hline & & $\mathrm{P}_{\text {PMH }}$ & 0.262 & $<0.001$ & $<0.001$ & - \\
\hline \multirow{7}{*}{$\begin{array}{l}\text { Mechanical } \\
\text { loader }\end{array}$} & \multirow{7}{*}{$\begin{array}{l}\text { Loading logs } \\
\text { onto the } \\
\text { trucks }\end{array}$} & SEG & - & $<0.001$ & - & 0.201 \\
\hline & & GAL & - & 0.459 & - & $<0.001$ \\
\hline & & SLG & - & $<0.001$ & - & 0.001 \\
\hline & & BAT & - & $<0.001$ & - & 0.001 \\
\hline & & $\mathrm{T}_{\text {cycle }}$ & - & $<0.001$ & - & $<0.001$ \\
\hline & & $\mathrm{V}_{\text {cycle }}$ & - & $<0.001$ & - & $<0.001$ \\
\hline & & $\mathrm{P}_{\mathrm{PMH}}$ & - & $<0.001$ & - & $<0.001$ \\
\hline
\end{tabular}

Bold values indicate significant effect on a probability level of at least $5 \%$.

\section{Discussion}

Analysis of the operational performance of harvesting system equipment

Estimation errors (Table 2) were due to variability of the operational performance of activities that, in turn, varied depending on interactions with factors such as the mean volume per tree, type of log assortment produced, extraction distance, slope, operator and among others. However, values of $\varepsilon$ did not exceed $10 \%$ for any of the activities.
Under conditions of lower mean tree individual volume, Pereira et al. (2015) reported slightly higher values of $P_{\mathrm{PMH}}$ for tree felling with a tracked feller buncher than those observed in the present study and lower values for extraction activity with wheeled skidder. The operational performance for manually processing large logs with a chainsaw (Table 2) was similar to that found by Leite et al. (2014), although the latter study was conducted in eucalyptus plantations with lower mean individual-tree volume.

TABLE 4: Regression equations to estimate the productivity of the tree extraction with wheeled skidder and loading log with mechanical loader for each of the two operators.

\begin{tabular}{lllll}
\hline \multicolumn{2}{l}{ Equipment: Wheeled skidder } & \multicolumn{3}{l}{ Function/activity: Tree extraction } \\
\hline Op & Fitted equation & Adj. $\mathrm{R}^{2}$ & $\mathrm{SE}\left(\mathrm{m}^{3} \mathrm{PMH}_{0}^{-1}\right)$ & $\mathrm{SE}(\%)$ \\
1 & $\mathrm{LN}\left(P_{\mathrm{PMH}}\right)=5.482-0.006 \mathrm{ED}$ & 0.358 & 62.71 & 42.96 \\
2 & $\mathrm{LN}\left(P_{\mathrm{PMH}}\right)=5.211-0.007 \mathrm{ED}$ & 0.430 & 31.79 & 38.41 \\
\hline \multicolumn{4}{l}{ Equipment: Mechanical loader } & \multicolumn{4}{l}{ Function/activity: Loading logs } \\
\hline Op & Fitted equation & Adj. $\mathrm{R}^{2}$ & $\mathrm{SE}\left(\mathrm{m}^{3} \mathrm{PMH}_{0}^{-1}\right)$ & $\mathrm{SE}(\%)$ \\
1 & $\mathrm{LN}\left(P_{\mathrm{PMH}}\right)=1.003-0.460 V_{\text {cycle }}{ }^{2}+3.320 \sqrt{ } V_{\text {cycle }}+1.686 \sqrt{\mathrm{LV}}$ & 0.678 & 27.23 & 36.30 \\
2 & $\mathrm{LN}\left(P_{\mathrm{PMH}}\right)=4.579+0.831 \mathrm{LN}\left(V_{\text {cycle }}\right)+0.217 \mathrm{LN}(\mathrm{LV})$ & 0.595 & 28.59 & 31.73 \\
2 & $\mathrm{LN}\left(P_{\mathrm{PMH}}\right)=4.542+0.675 \mathrm{LN}\left(V_{\text {cycle }}\right)+0.304 \mathrm{LN}(\mathrm{LV})$ & 0.550 & 26.49 & 38.36 \\
\hline
\end{tabular}




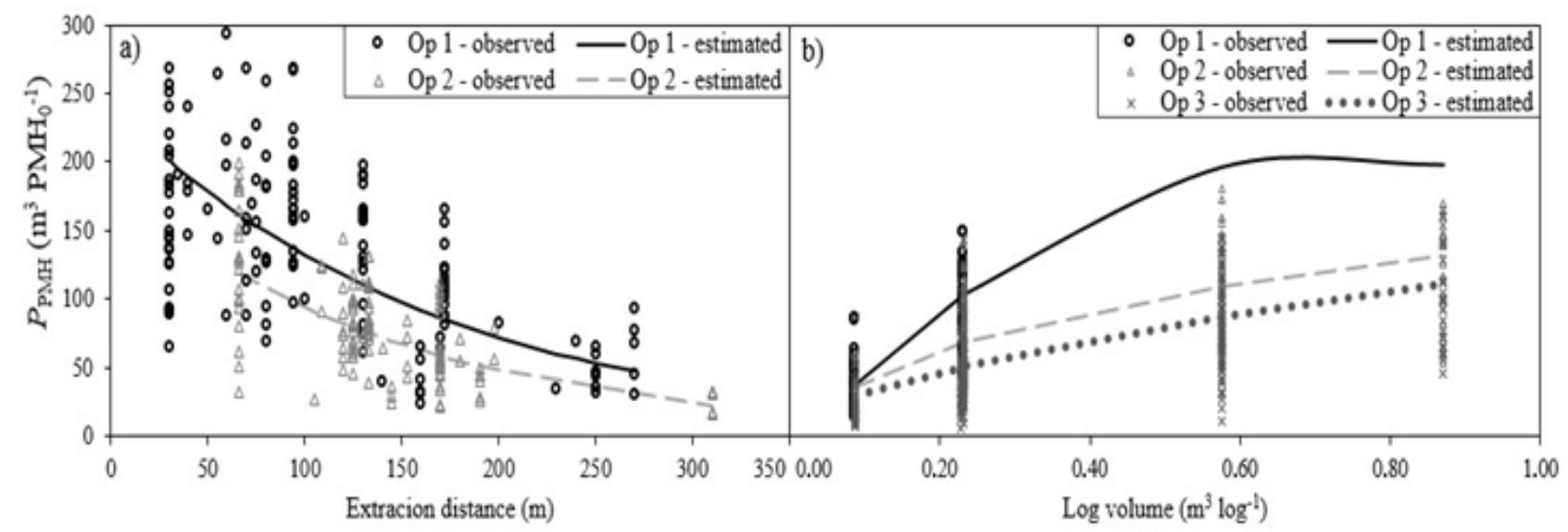

FIGURE 2: Productivity per operator as a function of extraction distance (a) and log volume (b) for wheeled skidder and mechanical loader, respectively.

The $P_{\mathrm{PMH}}$ of processing medium size logs with the mechanical slasher was higher than the value reported by Conrad IV and Dahlen (2019) and the $P_{\mathrm{PMH}}$ of processing small logs with the excavator-based harvester was also higher compared with that reported by Ghaffariyan et al. (2012) and Scorupski et al. (2017), however, the operational conditions of these studies were different. The values of $P_{\mathrm{PMH}}$ for log loading with a mechanical loader reported by Ghaffariyan et al. (2012) were higher compared with present study, although in conditions of higher mean log volume.

It should be noted that in most published studies, one piece of equipment performs all the tree bucking and processing operations in the WT harvesting system, which differs from the system studied here. This characteristic leads to a higher probability of occurrence of production bottlenecks, requiring attention in operational management to avoid this. In the current study, although the harvester had the highest $P_{\mathrm{PMH}}$, several delays occurred mainly due to corrective maintenance of the harvester head, resulting in the lowest $A R$ value and, consequently, a relatively low $U R$. The wheeled skidder $A R$ value was relatively high, and its $U R$ was the highest, with delays due to auxiliary activities. In moments of "excess production time", equipment performed other functions (support or production at another stage). Therefore, better mechanical maintenance practices and use of the equipment according to the limits of technical capacity, can improve the excavator-based harvester availability and increase the overall system production.

Low operating performance was expected for manual processing with a chainsaw due to this being the only non-mechanised activity within the harvesting system. The need to wait for the trees on the roadside landing area to be organised at the end of each extraction cycle of the wheeled skidder caused most of the delays. Hence, greater attention to operational management is required so that this activity does not become the bottleneck of the production system, especially because it is more susceptible to adverse weather conditions and, thus, subject to the risk of accidents and low UR (Shrestha et al. 2005; Silayo \& Migunga 2014; Fulvio et al. 2017), as observed in present study.
The $A R$ of the mechanical slasher and excavatorbased harvester processing medium and small logs, respectively, was relatively high. The delays due to rework and organisation logs in product stacks at roadside for subsequent loading reduced considerably the equipment $U R$. The mechanical loader had the lowest $U R$, which was due to delays caused by waiting for transport vehicles or displacement between log piles or roadside landing areas.

It is important to highlight that the ratios reported may not reflect the real proportion of availability and utilisation due to this study being short-term. Longterm studies are recommended for more accurately determining the usage ratios, as well as for estimating delays (Spinelli \& Visser 2008; Magagnotti \& Spinelli 2012).

\section{Factors affecting performance and modelling of productivity}

Terrain slope had a significant effect on some elements of the tree felling work cycle with the excavator-based harvester and extraction with the wheeled skidder (Table 3). It is expected that the increase in terrain slope increases the degree of work difficulty and, consequently, the operational safety risks. However, this factor had no significant effect on $T_{\text {cycle }}$ and $P_{\mathrm{PMH}}$, which possibly occurred because the maximum inclination observed in this study was only 9 degrees and, therefore, did not impose any major restrictions on equipment mobility. In clearcutting of a Pinus plantation with a lower mean individual tree volume, Diniz et al. (2018b) reported that the wheeler skidder performance only tended to be negatively affected when the slope was above 26 degrees. On lesser slopes, the operator was able to compensate for increased cycle times on steeper areas by working more quickly on the flatter areas, thus avoiding any productivity reduction. The operator had a significant effect on most of the operational performance variables of the wheeled skidder and the mechanical loader (Table 3) and, therefore, regression equations were fitted to individual operators (Table 4). For both types of equipment, the $P_{\mathrm{PMH}}$ was greater for the more experienced operator (Op. 1 in Figure 
2a,b), which suggests that it is important to invest in people development and training in order to improve performance in forest operations.

The predictability and effect of extraction distance on operational performance of the wheeled skidder is widely reported in the scientific literature for various equipment and operational conditions (Behjou et al. 2008; Rocha et al. 2009; Ghaffariyan et al. 2012; Walsh \& Strandgard 2014; Strandgard et al. 2017). In the case of the mechanical loader, log volume had a significant effect on most of the operational performance variables (Table 3) and, thus, was included as predictive factor for estimating the $P_{\mathrm{PMH}}$ in all regression equations (Table 4). There was a tendency to increase the $P_{\mathrm{PMH}}$ as the log volume increases (Figure 2b), similar to observations made by Diniz et al. (2018c) for other operational conditions.

\section{Conclusions}

The operational performance of the equipment in the harvesting system studied was variable and dependent on the effect of the operator, extraction distance and log volume. For this reason and because it has more equipment and a greater number of processing stages than most of the whole-tree systems that have been studies, there is greater likelihood of production bottlenecks, requiring attention in operational management to avoid or minimise this.

The use of models to estimate productivity considering such mentioned factors and reduced delays to increase availability and utilisation of equipment will contribute to the better management and planning of forest harvesting operations under the evaluated conditions.

\section{Competing interests}

The authors declare that they have no competing interests.

\section{Acknowledgements}

The authors would like to thank staff from Agroflorestal Paquerê without whom this study would not have been realised, the Foundation for Research Support of the Santa Catarina State (FAPESC) case number 2019TR657 for the financial assistance to the research groups, and reviewers for the constructive and helpful feedback.

\section{Authors' contributions}

Conceptualisation: NP, JS and PS; Methodology: JS, MB, and RR; Formal Analysis: all authors; Writing - original draft: NP and JS; Writing - review \& editing: all authors; Project Administration: JS; Funding acquisition: JS. All authors read and approved the final manuscript.

\author{
Abbreviations \\ Adj. $\mathrm{R}^{2}$ adjusted determination coefficient \\ AO_stems accumulation and organisation \\ $A R \_$availability rate \\ BAT_bunking the logs at the truck \\ BF_boom swing towards a tree and felling \\ BM_boom movement \\ CTL_cut-to-length \\ DB_drop and tree bunch organisation \\ ED_extraction distance \\ GAL_grappling logs \\ GLM_general linear model \\ LM_log measurement \\ LN_neperian logarithm \\ LV_log volume \\ $\mathrm{m}^{3}$ _cubic meter over the bark \\ ML_maneuvering and loading \\ MV_movement \\ n_number of observations \\ Op_operator \\ $\mathrm{PMH}_{0}$ - productive machine hour without any delays \\ $P_{\mathrm{PMH}-}$ productivity per productive machine hour \\ PR_processing logs \\ S_seconds \\ SB_stems bucking \\ SE_estimated standard error \\ SEG_swinging empty grapple \\ SG_swinging loaded grapple with logs \\ SLG_swinging logs toward the truck \\ TB_tree bucking \\ $T_{\text {cycle- }}$ total time consumption per work cycle \\ TE_travelling empty \\ TL_travelling loaded \\ UM_unloading and manoeuvring \\ $U R$ utilisation rate \\ $\mathrm{V}_{\text {cycle-Volume produced per work cycle }}$ \\ WT_whole tree \\ E_sampling error
}

\section{References}

Ackerman P., Gleasure E., Ackerman S. \& Shuttleworth B. (2014). Standards for time studies for the South African forest industry. ICFR/FESA, South Africa. $49 \mathrm{p}$.

Alvares A.C., Stape, J.L., Sentelhas, P.C., de Moares Gonçalves, J.L. \& Sparovek, G. (2013). Köppen's climate classification map for Brazil. Meteorologische zeitschrift. 22, 711-728. https:// doi.org/10.1127/0941-2948/2013/0507

Behjou F.K., Majnounian, B., Namiranian, M. \& Dvořák, J. (2008). Time study and skidding capacity of the wheeled skidder Timberjack 450C in Caspian forests. Journal of Forest Science, 54(4),183-188. https://doi.org/10.17221/5/2008-JFS

Björheden R., Apel K., Shiba M. \& Thompson M.A. (1995). IUFRO Forest work study nomenclature. Department of Operational Efficiency, Swedish 
University of Agricultural Science, Garpenberg, Sweden. 16 p.

Conrad IV J.L. \& Dahlen J. (2019). Productivity and cost of processors in whole-tree harvesting systems in southern pine stands. Forest Science, 65(6), 767775. https://doi.org/10.1093/forsci/fxz036

Diniz C.C.C., Robert R.C.G. \& Vargas M.B. (2018a). Avaliação técnica de cabeçotes individual e múltiplo no processamento de madeira. Advances in Forestry Science, 5(1), 253-258.

Diniz C.C.C., Nakajima, N.Y., Robert R.C.G. \& Dolácio, C. (2018b). Performance of grapple skidder in different ground inclinations. Floresta, 49, 41-48. https://doi.org/10.5380/rf.v49i1.55744

Diniz C.C.C., Cerqueira C.L. \& Oliveira F.M. (2018c). Influência do sortimento de toras na produtividade de um carregador florestal. Agropecuária Científica no Semiárido, 14(3), 247-253. https://doi. org/10.30969/acsa.v14i3.1050

Forestry Commission UK. (1996). Terrain Classification. Available: Accessed 01 December 2020. http:// www.biomassenergycentre.org.uk

Fulvio F.D., Abbas, D., Spinelli, R., Acuna, M., Ackerman, P. \& Lindroos, O. (2017). Benchmarking technical and cost factors in forest felling and processing operations in different global regions during the period 2013-2014. International Journal of Forest Engineering, 28(2), 94-105. https://doi.org/10.10 80/14942119.2017.1311559

Ghaffariyan M.R., Sessions J. \& Brown M. (2012). Machine productivity and residual harvesting residues associated with a cut-to-length harvest system in southern Tasmania. Southern Forests, 74(4), 229235. https://doi.org/10.2989/20702620.2012.74 $\underline{1770}$

Leite E.S., Carlos, F.H., Guedes, I.L. \& Amaral, E.J. (2014). Análise técnica e de custos do corte florestal semimecanizado em povoamentos de eucalipto em diferentes espaçamentos. Cerne, 20, 637-643. https://doi.org/10.1590/010477602014200413 $\underline{40}$

Lopes, E.S., Oliviera, D., Rodrigues, C.K. \& Drinko, C.H. (2017). Variables influencing working time and skidder productivity in wood extraction. Nativa, 5(4), 298-302. https://doi.org/10.5935/23187670.v05n04a12

Magagnotti N. \& Spinelli R. (2012). Good practice guidelines for biomass production studies. Sesto Fiorentino, Cnr Ivalsa.

Marčeta D.\& Košir B. (2016). Comparison of two felling and processing methods in beech forests. Croatian Journal of Forest Engineering, 37(1), 163-174.

Pajkoš M., Klvač, R, Neruda, J. \& Mishra, P.K. (2018). Comparative time study of conventional cut-tolength and an integrated harvesting method-a case study. Forests, 194(9), 1-10. https://doi. org/10.3390/f9040194

Peel M.C., Finlayson, B.A. \& McMahon, T.A. (2007). Updated world map of the Köppen-Geiger climate classification, Hydrology and Earth System Sciences, 11, 1633-1644. https://doi.org/10.5194/hess-11$\underline{1633-2007}$

Pereira A.L.N. et al (2015). Análise técnica e de custo do feller buncher e skidder na colheita de madeira em diferentes produtividades do povoamento. Ciência Florestal, 25, 981-989. https://doi. org/10.5902/1980509820659

Rocha E.B., Fiedler, N.C., Alves, R.T. \& Lopes, E.S. (2009). Produtividade e custos de um sistema de colheita de árvores inteiras. Cerne, 15, 372-381.

Rodrigues C.K., Lopes E.S., Pereira A.L.N. \& Sampietro J.A. (2019). Effect of individual tree volume on operational performance of harvester processor. Floresta, 49(2), 345-352.https://doi.org/10.5380/ rf.v49i2.58233

Seixas F. \& Oliveira Júnior E.D. (2001). Compactação do solo devido ao tráfego de máquinas de colheita de madeira. Scientia Forestalis, 60, 73-87.

Shrestha S.P., Lanford, B.L., Rummer, R.B. \& Dobois, M. (2005). Utilization and cost of log production from animal logging operations. International Journal of Forest Engineering, 16(2), 167-180. https://doi.org /10.1080/14942119.2005.10702524

Silayo D.S.A. \& Migunga A. (2014). Productivity and costs modeling for tree harvesting operations using chainsaws in plantation forests, Tanzania. International Journal of Engineering \& Technology, 3(4), 464-472. https://doi.org/10.14419/ijet. v3i4.3407

Souza F.L., Sampietro, J.A., Dacoregio, H.M., Soares, P.R.C., da Silva Lopes, E. \& Quadros, D.S. (2018). Densidade ótima e aceitável de estradas na colheita de pinus no sistema de toras curtas e árvores inteiras. Scientia Forestalis, 46(118), 189-198. https://doi. org/10.18671/scifor.v46n118.05

Spinelli R., Lombardini C. \& Magagnotti N. (2014). The effect of mechanization level and harvesting system on the thinning cost of Mediterranean softwood plantations. Silva Fennica, 48(1), 1-15. https://doi. org/10.14214/sf.1003

Spinelli R. \& Visser R. (2008). Analyzing and estimating delays in harvester operations. International Journal of Forest Engineering, 19(1), 36-41. https:// doi.org/10.1080/14942119.2008.10702558

Strandgard M., Mitchell R. \& Acuna M. (2017). Time consumption and productivity of a forwarder operating on a slope in a cut-to-length harvest system in a Pinus radiata D. Don pine plantation. Journal of Forest Science, 63(7), 324-330. https:// doi.org/10.17221/10/2017-JFS 
Strandgard M., Walsh D. \& Acuna M. (2013). Estimating harvester productivity in Pinus radiata plantations using StanForD stem files. Scandinavian Journal of Forest Research, 28(1), 73-80. https://doi.org/10.1 $\underline{080 / 02827581.2012 .706633}$

Szewczyk G., Sowa, J.M., Kamiński, K., Kulak, D. \& Stańczykiewicz, A. (2017). Selection of time study methods for forest operations. Forestry Letters, 110, 1-12.

Walsh D. \& Strandgard M. (2014). Productivity and cost of harvesting a stemwood biomass product from integrated cut-to-length harvest operations in Australian Pinus radiata plantations. Biomass and Bioenergy, 66, 93-102. https://doi.org/10.1016/j. biombioe.2014.01.017 